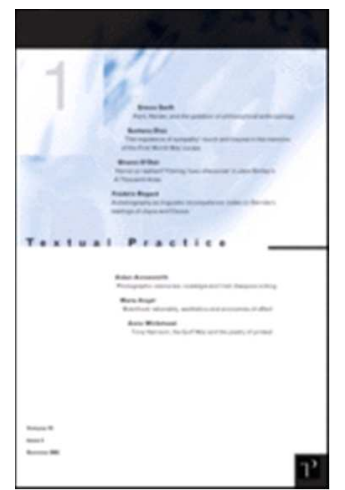

\title{
Information Overload in Literature
}

\begin{tabular}{|r|l|}
\hline Journal: & Textual Practice \\
\hline Manuscript ID: & Draft \\
\hline Manuscript Type: & Original Article \\
\hline Keywords: & $\begin{array}{l}\text { Literature, Digital Humanities, Cognitive Neuroscience, Informatics, } \\
\text { Memory }\end{array}$ \\
\hline
\end{tabular}

\section{SCHOLARONE}

Manuscripts 


\section{Information Overload in Literature}

Keywords: Literature; Digital Humanities; Informatics; Digital Mass Media; Technological Innovation; Cognitive Neuroscience; Memory; 'Chunking'; Anxiety.

Summary: This essay is the first to historicise and give a comprehensive assessment of literary responses to cognitive overstimulation. A wave of post-war writing responded playfully to informatics in a pre-digital period through an engagement with physics, entropy and post-structuralist theory. In an era dominated by neuroscientific revolutions, fiction written in the digital age addresses the pressing information overload debate with a new seriousness, stressing concerns about the impact on the human mind. Contemporary fictional writing depicts an increasingly immersive online experience that accelerates the demand for information processing by human minds under technostress. New phenomena such Big Data and 'infobesity' not only affect writing practice but also stretch the mainstream novel form to its representational limits. Mainstream literature responds to the changing shape of our lives and minds predominantly at the level of content, yet fails to find new forms of storytelling. This essay ends by identifying new writing that unites form and content in innovative ways by engaging with storytelling modes that guide us towards a new literary synthesis and aesthetic that represents the processes we are living through more accurately. We are living through a major epistemological shift, and are witnessing the emergence of new and exciting subjectivities.

\section{Introduction: a new dark age, or a world of perpetual light?}

This essay explores how the novel can help us understand the changing state of human cognition, memory and social behaviour in the twenty-first century. The incredible amount of information we are asked to contend with in the digital age is key to understanding our contemporary world. The overarching question of this essay is whether we are living through a new dark age, or, as the protagonist of Dave Eggers's The Circle (2013) hopes, we are making our way to 'a new and glorious openness, a world of perpetual light.' ${ }^{, 1}$ This opposition 
is founded on the paradox that, although we are led to believe that our digital habitus is an open, transparent and democratised mediascape in which information is readily and freely accessible to everyone, making sense of this proliferation of information is much more difficult as interpretation is progressively more obscure. As quantity triumphs over quality, we are all becoming increasingly information rich and knowledge poor, as science writer James Gleick notes in The Information (2011): 'Another way to speak of the anxiety is in terms of the gap between information and knowledge. A barrage of data so often fails to tell us what we need to know. Knowledge in turn, does not guarantee us enlightenment or wisdom. ${ }^{2}$ Gleick describes information overload in negative terms, focusing on new concerns arising about the growing avalanche of information. He identifies 'information anxiety' and 'information fatigue' - in short, the feeling that we just cannot keep up with the amount of facts, events, data, images, documents, messages and points of view on the world around us. ${ }^{3}$ Alvin Toffler first theorized 'information overload' in his book Future Shock (1970), noting that our sanity

hinges on man's ability to predict his immediate, personal future on the basis of information fed to him by the environment. When the individual is plunged into a fast and irregularly changing situation, or a novelty-loaded context, however, his predictive accuracy plummets. He can no longer make the reasonably correct assessments on which rational behaviour is dependent. ${ }^{4}$

In the digital age, overload has resulted in technostress maladies structured around, as Clay Johnson's The Information Diet (2012) investigates, food metaphors such as 'infoholicism', 'infobesity', 'data addiction', 'infostress' ${ }^{5}$; in short, the over-consumption of information that leads to distraction and an inability to concentrate and make decisions, fatigue and sleeplessness, and anxieties about social exclusion, social death, loss of identity and authority. ${ }^{6}$ New technologies, and the endless data they generate, are undermining traditional idea about selfhood, as Donald E. Hall notes. ${ }^{7}$ Bernard Stiegler argues that information is a black box whose contents only become wisdom through an interpretative process that codes and conditions the knowledge which it produces. Knowledge about the world beyond the subjective self has become increasingly conditional and relative as the processes that turn information into knowledge have become even more difficult to understand and control due to various contingencies and uncertainties built into our present - one may think of destabilising 
events such as Black Swans and global processes such as climate change. As a result, knowledge has become of less value and we are left in a state of indeterminacy. ${ }^{8}$

The debate about knowledge, cognition and memory can be illuminated by the stand-off between the cautionarists and reluctant optimists. In The Shallows (2010), Nick Carr argues that our brain and human behaviour are irrevocably changed by the internet, and that the distraction integral to our online experience prevents us from deep thinking, which also affects our capacity for empathy and compassion. Psychogeographer Will Self has criticized GPS, suggesting that it undermines the natural navigational skills of the brain ${ }^{9}$, and George Steiner notes that human nature has changed because the internet gives us the capacity to look up anything, so that we don't need to remember anything anymore. ${ }^{10}$ Other critics who warn against the detrimental impact of the digital include Viktor Mayer-Schönberger, neuroscientist Susan Greenfield and Joshua Foer. In the other camp we find Clive Thompson, whose Smarter Than You Think (2013) argues that technology augments our minds, and that we should celebrate scientific innovations. Cognitive scientists such as Itiel Dror and Stevan Harnad also show that our mental capacities are not simply lost because of new cognitive technologies, but that they are changing, and that they might well trigger the next step in our evolutionary development. ${ }^{11}$

My reading of modern literature here shows us that we have been living through a major epistemological shift caused by two interrelated developments. On the one hand, the digital age has subjected us to an increasing cognitive overstimulation and the resulting exhaustion has caused our defences against these mental impacts to weaken. On the other hand, technologies have become integrated into our bodies, brains and minds to create an immersive, extended experience, which has major implications for our individual identity and society. Despite new social benefits, access to information and feeling of bliss generated by new technologies and social media, we are seeing the emergence of a new human being whose nature is paradoxical, contested and controversial. The acceleration, and refined way, with which we today extend and offload our mind's capabilities and content using external tools and storage devices has increased our connection with the world and other people and perfected Freud's 'prosthetic god,' whereby minds seeps and leaks out into the world, creating a dynamic, symbiotic cognitive circuitry that extends the self beyond the confines of the brain and body. $^{12}$ 
By historicizing literary responses to cognitive overstimulation this essay makes the case for a shift in thinking about the human subject in relationship to informatics. Post-war writing produced in a predominantly offline environment understands the relationship between knowledge and informatics mainly in entropic and post-structuralist terms, in a utopian celebration of the potential subversive freeplay of noise - unwanted signals that modify the legibility of transmitted data. The digital revolution sees a concomitant paradigm shift in theoretical conceptualisation of the human subject and culture, which are framed in neuroscientific terms, side-lining the humanities as an ideology. I will read current concerns for authenticity, attention span and a range of emergent psychopathologies through a series of recent novels that depict and problematize this new form of mind. I argue that the mainstream novel has, in its attempt to cling onto, and defend, the increasingly peripheral ideology of humanism and its artistic traditions, not yet found an adequate formal response to representing the way in which today's technology and informatics are reshaping our increasingly posthuman world. I also identify a number of new literary projects that unite form and content in innovative ways to represent and respond to the digital revolution in new ways in a plurality of modes and media. These new fictions guide us towards a new literary synthesis and aesthetic that represents the processes we are living through in a more satisfying way.

\section{Literary responses to informatics in the pre-digital age}

Questions about the relationship between people and information are ancient, dating back to at least six millennia ago, when the Sumerians invented the sexagesimal, the first numeral system. This support structure for trade and money was passed down to the Babylonians and refined by the Mesopotamians, simultaneously giving birth to writing. As Katherine E. Ellison notes in her book on information overload in the eighteenth century, '[e]very age has been an information age, ${ }^{, 13}$ an observation echoed by Ann Blair's investigation of sixteenth- and seventeenth century scholarship, Too Much To Know (2011). Alex Wright goes so far as to argue that the 'information age started not with microchips or movable type, but with the first flowering of complex life' two million years ago, even though there was no human consciousness to observe it. ${ }^{14}$ Tom Standage notes that the increasing volume of information in the nineteenth century caused by the telegraph and the stock ticker drove people insane. ${ }^{15}$ In Victorian times, Charles Dickens famously parodied the ever-growing amount of information and accompanying bureaucracy by inventing the Circumlocution Office in Little 
Dorrit (1955-57), a comment on the growing administration Empire required. Modern literary history has seen a consistent response to information overload, from Jonathan Swift's 'The Battle of the Books' in A Tale of the Tub (1704) and Edgar Allen Poe's 'The Power of Words' (1845) to Jorge Luis Borges's ‘The Library of Babel' (1941) and Gertrude Stein, who in 'A Reflection on the Atomic Bomb'(1946) noted that '[e]verybody gets so much information all day long that they lose their common sense. ${ }^{16}$ In The Metropolis and the Mental Life (1903), sociologist Georg Simmel decried the sensory overload generated by the modern city. While James Joyce's encyclopaedic project attempts to create a totalizing view to make sense of the increasing amount of information, Kafka's dehumanised protagonists are lost in labyrinths of bureaucracy. T. S. Eliot's pageant play The Rock (1934) asks questions about the superabundance of information that inhibits sense-making processes: 'Where is the wisdom we have lost in knowledge?/ Where is the knowledge we have lost in information? ${ }^{17}$

Our 'information age' emerged in the late forties, sped up by 'the industrialisation of the code breaking processes enabled by machines such as the Turing/Welchman Bombe and the world's first electronic computer, Collossus,' at Bletchley Park during the Second World War. ${ }^{18}$ Claude E. Shannon's paper 'A Mathematical Theory of Communication' (1948) lies at the basis of theorizing information, leading to The Mathematical Theory of Communication (1963), which contains a non-technical introduction by William Weaver that allows a lay audience access to the theoretical difficulty of Shannon's original work. These pioneers of communication theory note that the chaotic proliferation of information conceived as a mathematical equation acts analogously to entropy, the second law of thermodynamics that states that within a closed system energy dissipates and disorder spontaneously grows until it maximises.

Weaver also suggests that unintended distortions of information - noise, signals, codes, which are all unintelligible and seemingly meaningless - contribute to the semantics of messages, as the diagram below shows. 


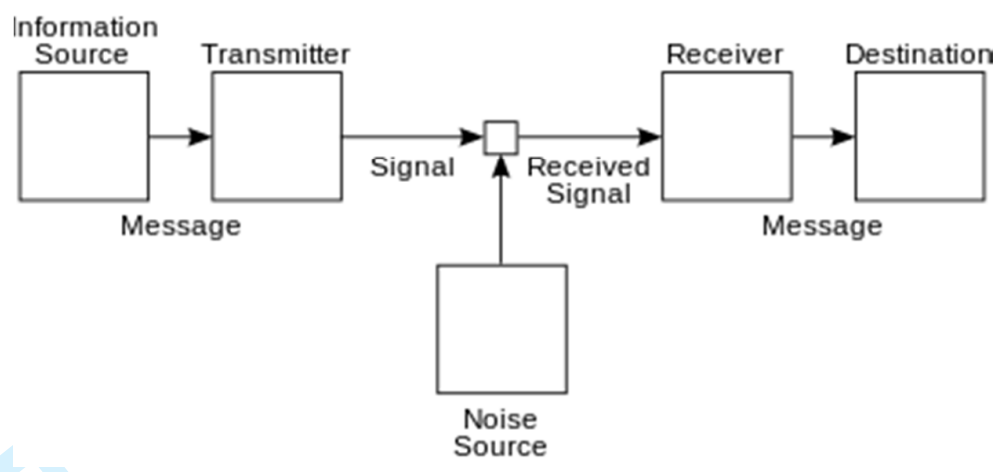

Warren Weaver's diagram of communication systems (1963)

Whether the sender intends communication to be intelligible does not matter: predictable messages are redundant because the intended content does not matter much. The opposite is true as well: potentially intelligible messages we send out are drowned out in a culture increasingly dominated by unwanted interference that distorts communication. The exponential growth in communication and the concomitant proliferation of noise have a detrimental impact on our body and brain as they costs bodily energy, whilst diminishing our ability to communicate; intelligible messages become distorted and biological energies are depleted. We filter and search, yet are left frustrated knowing that even the facts and answers we find are compromised by the sense that we have no fixed, totalizing overview.

Informatics saw a first wave of literary responses in key post-war writing such as Joseph Heller's Something Happened (1974), William Gibson's Neuromancer (1984), Don DeLillo’s White Noise (1985), Haruki Murakami’s Hard-boiled Wonderland and the End of the World (1985), David Foster Wallace's The Broom of the System (1987) and Richard Powers's The Gold Bug Variations (1991). These novels all draw on scientific thinking about informatics, encryption, coding and noise to understand the changing nature of the late capitalist world. This scientific engagement develops in tandem with the first intellectual response to information overload in Guy Debord's Society of Spectacle (1967), a manifesto against the way in which an avalanche of representational forms in the twentieth century (media such as newspapers, film, TV etc.) both forced people to live at the level of representation rather than the 'real,' whilst social relationships were mediated through, and manipulated by, these representational forms. In the United Kingdom, J. G. Ballard investigates the implications of Spectacle in works such as The Atrocity Exhibition (1969) and Crash (1974), yet the earliest Ballard story that engages with information is 'The Overloaded Man' (1961), in which the protagonist, Harry Faulkner, is bombarded with impressions and information, and goes 
insane. He quits his job and decides to 'switch off the world' by dematerialising his environment through a process of 'massive effort of concentration' that allows him to obliterate spaces, bodies, and impressions through abstraction and 'pure ideation., ${ }^{19}$ Anthony Burgess's dystopian A Clockwork Orange (1962) invents the 'Ludovico Technique,' an experimental behaviour modification therapy whereby graphically and sexual violent films recondition the unruly protagonist, Alex. Strapped into a contraption that holds open his 'glazzies' (eyes) he is forced to 'viddy' (watch) films until the overload, in conjunction with injections, make him utterly sick. ${ }^{20}$

Literature shows two kinds of responses to information overload. In traditional, mainstream literature that aligns itself with the humanist legacy we find a retrenching to the old-fashioned notion of the novel as an ordering device that restores the chaotic world back to order until it makes sense again (at least within the novel). And yet, there are also radical, experimental forms of literature that mimic informational streams and accelerate chaos in order to investigate the effects of interference and distraction upon the human mind. In the States, two of these responses came with William Burroughs's The Ticket That Exploded (1962) and Thomas Pynchon's ‘Entropy' (1960) and The Crying of Lot 49 (1966). Burroughs's novel tells the story of earth's invasion by the Nova mob, which brings increasing chaos to our world. ${ }^{21} \mathrm{Mr}$ Lee, an agent recruited by the Nova police, needs to counter this extreme chaos by subjecting himself to the increasing forces of uncertainty and instability. Lee absorbs information coming from newspapers, signs that regulate public life, films, etc. until he becomes chaos. Important here is Burroughs's injection of chance components, repetition and contingency - noise - into the form of the novel, which mimics entropic processes and the way in which noise undermines the intelligibility of communication. Philipp Schweighauser observes that in The Crying of Lot 49, Pynchon develops the idea of a machine built by Nefastis in which 'informational entropy' counters thermodynamic entropy and thus creates order and saves energy. ${ }^{22}$ In his discussion of this hypothetical machine - or black box - with protagonist Oedipa Maas, Nefastis explains that he needs a kind of anti-Maxwell's Demon (a 'sensitive') that reverses entropic regression, which is connected to information through metaphor, and from there to human culture, behaviour and communication:

'Help,' said Oedipa, 'you're not reaching me.' 
'Entropy is a figure of speech, then,' sighed Nefastis, 'a metaphor. It connects the world of thermodynamics to the world of information flow. The Machine uses both. The Demon makes the metaphor not only verbally graceful, but also objectively true.'

'But what,' she felt like some kind of heretic, 'if the Demon exists only because the two equations look alike? Because of the metaphor?' 23

In Pynchon, the entropic concerns comment metaphorically on the state of subjectivity and culture in the post-war world determined by miscommunication and misinterpretation, leading to cultural paralysis and degradation of language, meaning and the self. For exponents of the sixties counter-culture such as Ballard, Pynchon and Burroughs, and their literary descendants such as David Foster Wallace and Tom McCarthy, failure to communicate, virus, error and glitches, deviation, disorganization, imperfection and anti-purpose become productive, meaningful and full of subversive potential. As Mark Nunes's Deleuzian reading of information theory argues: 'In the moment of equivocation - [...] in the interstitial space between signal and noise - slippage, error, and misdirection suggest an opening onto a potential outside of purpose and control. ${ }^{24}$

In the late seventies, a more realist response to information came with Ian McEwan's teleplay The Imitation Game (1981). Set in 1940 amid the widespread unease over a potential German invasion, piano player Cathy Raine joins the Auxiliary Territorial Service (ATS), becomes an interceptor writing down codes, and ends up as a dogsbody at Bletchley Park. The screenplay is McEwan's exploration of the relationship between, on the one hand, gender discrimination and sexuality, and, on the other hand, male-dominated power and informatics. Cathy falls in love with Turner, a veiled version of Alan Turing, who explains that his famous experiment on artificial intelligence, the eponymous 'imitation game,' which attempts to replace consciousness with a machine, has a gender bias. ${ }^{25}$ McEwan's script presents us with a too conveniently neat parallel between secrecy of patriarchal military power and the exclusion of women, that is, an easily decodable 'message' about male power over knowledge and power. More interesting is the 'noise' that distorts rationality and socio-sexual behaviour of humans:

TURNER. And you deliberately misunderstand me. Why are you so prickly?

CATHY. Why are you so interested?

TURNER. I like difficult, prickly people. They’re awfully intriguing. 
CATHY. Just like difficult codes. ${ }^{26}$

The wider implication of the equation of human communication with codes is, again, to stress the increasing noise and unintelligibility of life and social relationships in modernity. On the mistaken assumption that she is spying for the Germans, Cathy ends up being tried and imprisoned. The Imitation Game shows that the result of the superabundance of information in a war-time context results in the misinterpretation of noisy 'intelligence,' reducing our capacity for rational thinking.

Open any page of Brett Easton Ellis's postmodern Gothic American Psycho (1991), a key example of engagement with information in Reagan's eighties, and a wealth of detail (fashion brands, names of clubs and restaurants, the joys of Phil Collins etc.) makes it clear that the novel is chronicling the effects of information overload on the late capitalist human being. As an extension of Spectacle into hellish hyperconsumerism, the protagonist's fetishisation of his and others' business cards shows that the world has become an endlessly coded place in which not only the content but also the form of data ise an endless source of information with increasingly indeterminate readings. In a world where everything is mediated, social, cultural, economic and sexual relationships are constructed via media and technology, which simultaneously function as sources of connection and blockage.

The year that saw the mass introduction of the Internet and email, 1995, also saw the publication of Martin Amis's The Information, which, on the surface, is about a midlife crisis. Amis is obsessed with entropy, however, from the 'heat death' in London Fields (1989) to the reversal of time in Time's Arrow (1991). From what Hayles calls an 'information perspective' the exploitation of redundancy and repetition in Amis becomes powerfully meaningful. ${ }^{27}$ As one critic wrote: 'His trademark style of using redundancy, of emphasis through incremental repetition, may be defined as maximalist. ${ }^{28}$ The novel's style embodies noise, which expresses itself in the distortion of communication between the characters, leading to existential indeterminacy. As the narrator Richard Tull says: 'how can I ever play the omniscient, the all-knowing, when I don't know anything? ${ }^{29}$

One might question, however, the usefulness of this appropriation of scientific terminology and frameworks by critics and writers. There is a distinct gap between the realms of physics and mathematics and that of literature and linguistics, and we can only understand and use 'informational entropy' if we understand it as a metaphorical concept, based on analogy. The desire of writers and, particularly, of scholars to work with scientific ideas and terminology is 
an ambiguous, potentially misguided, undertaking. It suggests, on the one hand, the humanist desire to connect with other disciplines and to humanise them, but this discourse of the human experience and the world of literature in terms of information does also suggest a partial subjection to science and its discursive and ideological operations. What is more, the term 'information age' was first coined by R. S. Leghorn as a positive notion in the $H$. $B$. Management Manual (1960), but most literature refuses to entertain such a potential. 'Information overload' was first alluded to by social scientist Bertram M. Gross in The Managing of Organizations (1964), which chronicled modernity's struggle with population expansion, the complexification of society and the concomitant intensification of bureaucracy, and the familiarizing of this term suggests that this Americanism is fully and comfortable lodged in our discourse. We are unquestioningly trapping ourselves in the language of submission to 'machines' rather than dismantling the ideological and discursive origins and logic on which information overload is founded.

\section{Neuro-centric conceptions of information overload in the age of the brain}

The impact and conceptualisation of information overload shifts markedly after 1995, partly because of what David Cronenberg calls 'the inexorable hot lava flow of technology, ${ }^{30}$ which has accelerated what David Foster Wallace calls 'the tsunami of available fact, context, and perspective that constitutes Total Noise' - infinite interference. ${ }^{31}$ Their use of organic metaphors underscores James Gleick's idea that with the rise of cybernetics ' $[w]$ e can see that information is what our world runs on: the blood and the fuel, the vital principle. ${ }^{32}$ However, the digital and Big Data have irrevocably restructured our posthumanist habitus, cognition and memory, generating anxieties about the diminished role of humans in the production of knowledge. A weekly edition of the New York Times contains more information than the average seventeenth century person in England would come across in his or her whole life, and between 1998 and 2000 the number of documents on the Internet doubled from 400 to 800 million. ${ }^{33}$ Bernard Stiegler writes:

This [information gathering and] processing does nothing but produce new information and augment the amount of available information, which is in turn processed, and so on. Given the speed of this calculation on the scale of our thought process, and our apperception capacity, information proliferates infinitely and is finally unprocessible for "us": we are too slow, can no longer be its receivers; we are 
no longer at the level of the processing problems spanning all the information that must them be processed without "us," and the implementation of automatic processing programs for buying and selling on the market, for example, is inevitable. ${ }^{34}$

In general we find a negative conceptualisation of information overload, associated with which are various psychopathologies, first theorized by Saul Wurman in Information Anxiety (1989), which was followed by critical books such as Theodore Roszak's The Cult of Information (1994), David Shenk's Data Smog: Surviving the Information Glut (1997), Clay Shirky's Cognitive Surplus (2010), and Johnson's The Information Diet (2012). The effects of information overload remain largely similar: memory loss, an inability to think rationally, a decrease in predictive abilities which inhibits skills such as making decisions. David Bawden and Lyn Robinson note that the loss of diverse forms of media, the increased homogenisation of information communication, the decontextualisation of information and the absence of information literacy have led to cognitive overload, attention deficit, and various anxiety pathologies in which the loss of identity and loss of control feature: 'Information anxiety [...] is usually taken to be a condition of stress caused by the inability to access, understand, or make use of, necessary information., 35

Simultaneously, as the nature of overload has changed, so has our theoretical contextualization, shifting from entropic concerns with its roots in physics to a focus on cognitive studies in which neuroscientific schemata dominate. Pynchon's Maxwell's Demon has become another kind of black box: the brain. Most contemporary critiques work from the idea that the brain is directly affected by events and sensation in the body and outside world; one might indeed say that both digital coding and flows of information, as well as nerves, operate via a binary language: synapses either fire, or not. Yet there are also a group of theorists who challenge this. From a systems theoretical and biological perspective the brain is operationally speaking a black box, a closed system with electrical-chemical physiology which is not directly in touch with the world and does not communicate directly with its environment, but only with itself through firing neurons, which means that the brain can never experience overload. In a book on radical constructivism Siegfried Schmid notes: 'An important insight brought forward by [Humberto] Maturana states that living systems are selfreferential systems in which information is closed within itself and determined by its own structures. There is no informational input and output; in other words, biologically we are open, but we are closed in informational terms. Rather, the system itself generates the information it processes during the operations of its own cognition. ${ }^{36}$ From this perspective, 
if the human brain were to be truly open as a precise cognitive system integrated into the world, then it would not be able to purposely control our actions but instead be overloaded with the avalanche of events in the outside world. Such ideas are echoed in John R. Searle's work; his The Mystery of Consciousness (1997) notes that we 'could never discover computational processes in nature independently of human interpretation because any physical process you might find is computational only relative to some interpretation. ${ }^{37}$ The computational model of the mind which underlies much of the criticism of information overload is, according to Searle, a wrong analogy:

The brain is indeed a machine, an organic machine; and its processes, such as neuron firings, are organic machine processes. But computation is not a machine process like neuron firing or internal combustion; rather, computation is an abstract mathematical process that exists only relative to conscious observers and interpreters. Observers such as ourselves have found ways to implement computation on silicon-based electrical machines, but that does not make computation into something electrical and chemical. $^{38}$

There exist various gaps between the human mind and the outside world psychophysiological, operational, and methodological - which many critics and writers ignore. It seems then that the organic metaphors of Gleick and some writers are representationally inadequate.

As Ian Glynn notes, there 'is a striking difference between the way in which we receive information by post or telephone or the Internet, and the way our brain receives information from our sense organs. The information we derive from a letter or telephone call or email, including the identity of the sender, is all in the message. [...] the messages our brain receives from our sense organs all consist of very similar impulses - action potentials. ${ }^{39}$ Nerves carry information along through impulses running through fibres, and meaningful information depends on the temporality and intensity of the impulses and the location of the activated fibres, not the size of the impulses: like digital coding, synapses are either firing or not firing. However, Glynn does bring back the importance of the human body, and its limits:

You might say that, given the enormous rate at which information nowadays is transmitted in digital signals, this limitation is not serious; but you would be wrong for two reasons. Firstly, as we have seen, nerves cannot transmit impulses at frequencies of more than a few hundred per second. And secondly, even at these low frequencies, 
encoding information in intricate time patterns is impossible because a nerve fibre that has just conducted several impulses in quick succession will conduct more slowly, so the pattern will become distorted as the message proceeds along the nerve.

At a cellular level there are limits to the ability of messages to be carried across intact: there is a definite biological boundary after which information receives interference by noise, or is not carried across at all.

Neuroscientist Torkel Klingberg's The Overflowing Brain (2009) also explores the impact of information overload on our brains in the digital age in the light of biological boundaries. Although we should dispute the title's false metaphor, Klingberg argues that current overload has a detrimental impact on cognition and, in particular, on working memory: 'As advances in information technology and communication supply us with information at an ever accelerating rate, the limitations of our brains become all the more obvious. Boundaries are defined no longer by technology but by our own biology. ${ }^{40}$ By drawing on neuroscientific evidence, Klingberg shows that working memory - our ability to remember information for a short period of time before we either discard information or store it in our long-term memory - is detrimentally affected by overload. The result is problematic. Working memory lasts for a short period of time (a few seconds), but is dependent on your ability to focus attentively on a particular piece of information through focused (and often visual) attention (like remembering which spot you parked your car in). This info is then transferred to your long-term memory, after which you no longer need the visual image as it is now retrievable from your long-term memory. The Overflowing Brain argues that, because of the distraction caused by information overload, working memory is impaired and not operative long enough for information to be stored in the long-term memory. This failure to encode information into our neuronal network also has a negative effect on our ability to solve problems, thus echoing Toffler's earlier analysis. ${ }^{41}$ This is partly because the human body and brain have biological limits: neuroscientists have shown that 'blood flow and metabolism gradually escalate in direct proportion to the amount of information' we are asked to process, but that there also is a metabolic limit that restricts the amount of information we can process. ${ }^{42}$

As concentration is undermined, writers in particular have seen their working practice attacked. Jonathan Franzen and Peter Buwalda seek to keep their concentration intact through self-isolation. To write, Franzen isolates himself from our 'noisy culture' and other distractions. ${ }^{43}$ For four years, Buwalda cut off all communications with the world to focus on 
this first novel, Bonita Avenue (2010). Buwalda returned to the idea of 'working like a monk,' the value of which is also underscored by the essayist Pico Iyer. ${ }^{44}$ Franzen and Buwalda showed how paradoxical the information age has become by complaining about noise on a very noisy medium, television. Franzen decried noise on the Oprah Book Club and Buwalda did a series of cognitive tests to investigate his attention span for Dutch television. ${ }^{45}$ Besides isolation and self-restraint, the digital age offers its own solutions: Dave Eggers is a champion of Freedom, and at a literary festival, Ian McEwan also told the audience he uses this internet blocker software. $^{46}$

Foster Wallace also laments overload, but his concept of 'Total Noise' should be scrutinised closely:

Maybe, given the ambient volume of one's own life's noise, the main difference will make sense to you. Writing-wise, fiction is scarier, but non-fiction is harder-because non-fiction's based in reality, and today's felt reality is overwhelmingly, circuitblowingly huge and complex. Whereas fiction comes out of nothing. Actually, so wait: the truth is that both genres are scary; they both feel like they're executed on tightropes, or abysses - it's the abysses that are different. Fiction's abyss is silence, nada. Whereas nonfiction's abyss is Total Noise, the seething static of every particular thing and experience, and one's total freedom of infinite choice about what to choose to attend to and represent and connect, and how, and why, etc. ${ }^{47}$

For Foster Wallace, non-fiction tries to represent, and make claims about, the world, and thus must grapple with an overloaded 'real.' Non-fiction is about creating order through making avail of a transparent language with a clear, one-dimensional informational structure. Good literature is different because its starting point comes from someplace else, according to Foster Wallace, and its semantics are more difficult to determine. The fictional world that is created in the imagination does not necessarily have its origins in our shared world: the signs which readers habitually construct into an imagined world are not necessarily connected to signifiers in that world 'out there.' Foster Wallace's logic is thus different from informational entropy and postmodernist paradigms (which suggest that both non-fiction and fiction are constructed), and both builds on, as well as reacts against, the intense and immersive experience created by the increased integration of the digital into our everyday lives. 


\section{In Code We Trust: information overload in the mainstream novel}

Here are just a few examples to show how ubiquitous the engagement with cognitive overload has become in mainstream literature which posits the novel as a making-sense device that orders chaos. An encyclopaedic fiction obsessed with information, Zadie Smith's first novel White Teeth (2000) traces the gap between a generation who lived through the Second World War and the post-war period, and a (post-)postmodernist generation who engage in a much more savvy way with the digital. Representative of the former generation, Archie Jones is unable to keep up with technology and puzzled by the deluge of information, and modern life in general. Here Archie contemplates the wealth of information on a bus ticket:

Cor (thought Archie) they don't make 'em like they used to. That's not to say that they make then any worse. They just make them very different. So much information. The minute you tore one from the perforation you felt stuffed and pinned down by some all-seeing taxidermist, you felt freeze-framed in time, you felt caught. Didn't use to be, Archie remembered. ${ }^{48}$

Archie feels monitored by technology which evokes paranoia, and criminalized by the detail of information which he experiences as a kind of death, and this is even before electronic ticketing (Oyster cards) in 2003. Smith also pinpoints the paradox that, rather than having an ordering effect, too much information creates noise and disorder.

In Tobias Hill's lit tech noir The Cryptographer (2003), tax inspector Anna Moore is tasked with investigating the quadrillionaire code maker John Law, whose invention of Soft Gold, an electronic currency, has made all other money obsolete, including the US dollar: "people trust it because of its code, which can never be broken. In Code We Trust. ${ }^{49}$ Set in a 2020s London, Anna's quest for fraud draws her into the life of the mysterious Law - 'a man whose life's work is to stop people understanding anything ${ }^{50}$ - and his world of mathematical information. Another cryptographer, Tunde Finch, explains that coding can turn everything into a mathematical pattern that can be used to make things disappear or be translated into something else. Cryptography is a beautiful science. ${ }^{51}$ It is not long after Anna falls in love with Law and discovers a Jane Eyre-esque secret that she succumbs to overload in the world of coding: 'Her computer fills up with the tiny icons of unopened messages. A monstrous haul of junk mail washes up from the Internet sites she has examined, even those she has never visited. ${ }^{52}$ Soft Gold succumbs to a virus, creating global turmoil, and Law, stripped of everything, becomes a hunted man. Information is mainly viewed in negative terms, a source 
of global stability. The novel's trajectory and Hill's subtle use of intertexts work against the increasing chaos of our posthuman culture by placing literary 'codes' underneath the mathematical coding making. At the start of the novel, Anna touches the pavement outside her Revenue office:

It was cool to touch and dark but also clear, like a window at night from the inside. The sensation she felt was not unlike vertigo. She saw - under her own reflected face the silicon chips. Hundreds and thousands of them, small as the tesserae in a mosaic. [...] Once she saw a read-out illuminate deep below the surface, like a coin falling into a well., 53

The pavement places both Anna and the digital age in deep evolutionary time. The grains of sand, at the heart of nature, and computer chips are connected through coding, and the passage thus brings to life, ironically, Blake's line 'To see the world in a grain of sand' in Auguries of Innocence (1803). This struggle between humanism and posthumanism continues in this passage's juxtaposition with T. S. Eliot's quest for sense in the age of information in The Rock, which Anna reads. The end of The Cryptographer gives us an anti-image to the pavement: when Anna meets Law at a remote Scottish island, and he invites her to sit down on a rock: 'She does, the rock rough and warm through her jeans. He takes her hand in his and looks away again, not letting go. ${ }^{54}$ This image harks back to, and inverts, Blake, whose plate 'Newton' (1795) is an ambiguous depiction of the enlightened scientist who turns his back on nature: the fallen cryptographer is re-humanised. Hill pinpoints the great disconnect between informatics and IT, and human beings.

Teju Cole's Open City (2011) focuses on the Nigerian immigrant Julius, a graduate student studying psychiatry in New York City, who spends most of his time walking in a somnambulant state across Manhattan, weaving a web of different knowledges based on an associative logic. One a number of occasions, Julian meets his mentor, the now retired emeritus Professor Saito: 'I don't read much either, he [Professor Saito] said, with the state my eyes are in; but I have enough tucked away up here. He motioned to his head. In fact, I'm full. ${ }^{55}$ Professor Saito's claim that his brain is literally full up relates to his imprisonment in an internment camp during the Second World War, when he memorized literature from Shakespeare to Wordsworth because he was unsure he would see his books again. By literalising the relationship between memory and the brain as material storage facility, this passage jokingly mocks our present neuro-centred culture, in which hardliners such as 
Antonio Damasio and Dick Swaab believe cognition depends on neural activity alone. ${ }^{56}$ By ironizing Klingberg's metabolic limits, Cole's novel becomes an anti-neuromaniac statement about the limitations of the human beings, asking how we should use our brains and what type of knowledge can potentially be offloaded whilst celebrating memory and the erratic, contradictory nature of human character.

In Haruki Murakami’s Colorless Tsukuru Tazaki and his years of Pilgrimage (2014), one of Tsukuru's friends notes:

We live in a pretty apathetic age, yet we're surrounded by an enormous amount of information about other people. If you feel like it, you can easily gather information about them. Having said that, we still hardly know anything about people. [...] It's more important that you meet them in person. You'll learn more that way. ${ }^{57}$

These literary responses have a hostile attitude to digital overload: despite the ostensibly beneficial impact on social relationships and on access of knowledge via technologies, they are deemed an obstruction to life and human communication. Lottie Moggach's 2013 novel Kiss Me First goes further by exploring the possibility of taking over someone's identity, digitally. The novel sees an autistic IT nerd and amateur philosopher, Leila, traumatized by her mother's death and holed up in her Rotherhithe flat with no interest in the outside world, become involved in a dark online cult that covers up suicides by artificially re-creating and perpetuating people's online lives. Leila is asked to assume Tess's identity but this proves a Sisyphean task:

There was so much information to deal with that I found that just recording things on my laptop wasn't enough. Ideally I'd have an extra screen to work from but I couldn't afford to buy one, so I ended up writing a chart on a big piece of paper with linking arrows, which I pinned up on my wall next to the photos. ${ }^{58}$

Leila has to remember Tess's social relationships with family, friends, lovers; her preference for clothing, food, culture; the main and minor events in her life; her way of writing online messages (including quirky spelling and grammatical errors) via email and through Facebook, etc. etc. As with Smith's bus ticket, this image points out that new technology turns us into detectives and criminals. The fact that Leila has to revert back to the materiality of paper is telling in itself: the volume of information generated by human lives, as well as their online existence, cannot be contained by the digital media that is partly responsible for producing it. 
In Eggers's The Circle, a Nineteen Eighty-Four (1949) for the twenty-first century, we follow the transformation of the twenty-something Mae Holland, who is employed by the world's most powerful internet company, the Circle, a not so thinly veiled allusion to Google. The Circle is trying to create a closed global system of communications in which everything, from weather conditions to the location of children, is known; this re-orders the world completely, democratically and from the bottom up, yet it also sees the demise of privacy and individualism. Holland transforms from a modest young woman who cares about her struggling family into an overly-ambitious corporate monster who rejects love, friends and family in favour of becoming the most liked media darling inside and outside the utopian totalitarian world of the Circle. The Circle extends, then, a genre that started with Goethe's Wilhelm Meister (1795-96): a Bildungsroman, but with a neurological slant. Starting at the bottom of the company in Consumer Satisfaction, Holland learns to think and live on three different levels, via a multiplicity of windows on two different computer screens that reprogramme her mind through a process neuroscientists call 'chunking', the ability to hold a multiplicity of sets of abstract data in the working memory and retrieve them as meaningful information. ${ }^{59}$ The average person is able to hold seven pieces of information in the working memory, but Holland is asked to do a lot more, pushing the metabolic limits of her body and exploiting the brain's plasticity to maximum degree. Simultaneously, she promotes herself as a public figure who needs to be recognized by others in the company in a way similar to getting 'likes' on Facebook. Through competition, the Circle pushes the need for recognition into new dimensions. Towards the end of the novel, having climbed the hierarchy of the company and lost sight of her family in the process, Mae is liked by 12,318 Circlers. She realises, though, that 368 Circlers had not liked her:

There were so many layers to all this, and while her mind was counting them, mapping them and naming them, her face and mouth had to carry on this conversation. [...] She needed to breathe. She needed to think. But there was too much in her head [...] The flash opened up into something much larger, an even more blasphemous notion that her brain contained too much. That the volume of information, of data, of judgements, of measurements, was too much, and that there were too many desires of too many people, and too many opinions of too many people, and too much pain from too many people, and having all of it constantly collated, collected, added and aggregated, and presented to her as if that all made it tidier and more manageable-it was too much. 
But no. It was not, her better brain corrected. No. You're hurt by these 368 people. This was the truth. ${ }^{60}$

Holland is in two minds: chunking has pushed her to the limits of her body's and brain's metabolic capacity, resulting in an anxiety about the potential breaking down of the rational patterns of thinking and decision-making processes so central to the Circle. She intuitively understands that the Circle's demands are 'too much,' yet built into the totalitarian logic of the Circle's cognitive brainwash is the overruling of such defeatism and relativism through a harnessing of utopian Circle think, in which men still control knowledge and power. This incorporates and pushes unconscious drives for dignity and self-worth to an extreme level: the Circle's recognition is pure, 'empty' prestige, without actual meaning or value. Eggers's character merges with information through chunking, yet this process is dependent on hyperrational thinking. As 'the simultaneous inflow of two streams of information is extremely demanding on the working memory' this inhibits long-term memory, and Holland soon forgets her family and the world beyond the Circle. ${ }^{61}$ This social amnesia occurs because interaction is dependent on working memory: to have a meaningful conversation with someone you need to focus on the present situation, the content of conversation, et cetera, but Holland's working memory has been overloaded by the Circle's demands. Holland thus suffers from a form of hyper-concentration needed for chunking activities and the Circle's coded language.

This list is by no means exhaustive but it does create a kaleidoscopic image of the many concerns about cognition, memory and of changing human nature in the digital age. Together this wide variety of fiction maps new subjectivities produced by overload. What is striking about these fictions is that they are making overstimulation their overt subject matter, wearing their concerns and anxieties on their fictional sleeves. Just as the 'appropriation' of scientific discourse by writers in the sixties partly led to an enslavement to the language of slavery, the overt fetishisation of 'information overload' and neurocentrism by cautionarists such as Klingberg, Eggers and Moggach et al. subscribes to, and reinforces, the validity of these theses. They also generate more noisewithout finding creative, subversive ways of resisting overload. The prolific production of Eggers and Murakami simply pumps more and more content into the system. In short, mainstream writing subjects itself to the very language of subjectification itself, and happily imprisons itself in the discourse of overload, thereby promoting it. 
Indeed, information could perhaps also be viewed in a positive light. In Parasite (1980), Michael Serres notes that noise and information are so ubiquitous in the world as well as in ourselves that we are united in this chaos as integral part of the human condition: 'We are in the noises of the world, we cannot close our door to their reception, and we evolve, rolling in the incalculable swell. We are hot, burning with life; and the hearths of this temporary ecstasy send out a truceless tumult from their innumerable functions. ${ }^{92}$ In How Pleasure Works (2010), Paul Bloom reminds us in a less lofty way that information has a vital structuring function within society: 'We have a hunger for social information, and celebrity gossip and fictional stories sate us with irrelevant tales of people who don't matter and people who don't exist. ${ }^{63}$ Gossip and other sources of (fictional) information are powerful modes of communication in the world, and we invite and thrive on this type of noise.

This raises the question of how in this paradoxical context the novel can harness its operational function of ordering the world and our minds. What is just as striking about the fiction mentioned above is that the forms of these novels do not necessarily represent the networked, de-hieracharised environment to which they respond. Hill and Moggach have written interesting thrillers, Hill with a wonderful sense of poetry, and Moggach by deftly exploiting a naïve narrator, but their choice of genre is telling. Perhaps one way of reacting against the big sprawl of data is to re-inject telos into the reading experience, which would, at least on a surface level, reintroduce the feel of purpose that Barthes argued against. Eggers's novel is nearly 500 pages long, narrated in chronological order, the dialogue flat and the writing is distinctly unembellished: if this aesthetic of disinterestedness represents the result of Holland's overloaded mind, the future of our thinking is bleak. All these novels are also centred on a single protagonist, which somehow does not quite capture the paradox of our complex spatial and temporal networked identities that both displace the importance of the self and re-affirm a strong self-identity. Smith's early novels, sprawling and encyclopaedic, are driven by an E. M. Forsterian desire to connect the informatics of genes and the digital with the humanist tradition; it is a Joycean totalising drive that aims to give an overview into the complexities of the twenty-first century world. All these novels cling on to humanist structures, and safeguard the human by giving their fictional narratives a relatively traditional form that essentially creates order in a world that feels increasingly out of joint. All the above fictions stay within the laws of the probable, and most routes into the improbable are often predictable - from FutureMouseTM escaping at the end of White Teeth as a predictable sign of an unpredictable future, and the rejection of Law in The Cryptographer, to Mae Holland's 
tragic transformation (i.e. the representational laws of the dystopia prescribe this) and Moggach's ending (which Tess thinks is open, but the reader realizes is not)- and thus also belong to the realm of the order. The upshot is that the digital is forcing the mainstream novel to operate beyond its adaptive range, stretching the novel to its representational limits.

\section{Digital Aesthetics}

There are a number of writers, however, who express overload both in the content and through the form of their work. David Foster Wallace's The Broom of the System and Infinite Jest (1996) engage with overload and informational entropy. The latter is a complex, sprawling undertaking that assesses the various addictions that modern life has in store for us, nesting and boxing stories, anecdotes and information within stories. Another author whose work responds to overload at the level of both content and form is Will Self. A former drink and drug addict, Self's sprawling verbosity, incorporation of unusual words, temporally complex plotting and difficult modernist style embody overload itself. Self trades on an aesthetic of exhaustion; his novels feel like a direct attack on the reader's mind and body, and have a rhizomic structure that mimics the structure of feeling of our age. ${ }^{64}$ It is significant that Foster Wallace and Self have had dependency issues: their work embodies the Serres quote above, and understands cognitive overstimulation by turning the self-world dynamic inside out: by inviting and embodying overload, their work merges with these processes so that they can be represented, understood, and worked through.

Tom McCarthy engages with overload differently. From his book Tintin and the Secret of Literature (2006), we already had an inkling of his obsession with post-structuralist theory, which McCarthy uses to explore noise, hidden codes and 'transmission zones' beneath the surface of Hergé's comic books. ${ }^{65}$ McCarthy notes: 'Enigma-solving is never straightforward. Hermeneutic sequences are full of what [Roland] Barthes describes as 'reticence.' The narrative sets up obstacles: delays, snares, partial or suspended answers and straightforward jamming. ${ }^{, 66}$ McCarthy is not just talking here about the ways in which a detective novel or thriller uses the distribution of information, but speaks on an epistemological and philosophical level, to the way in which readerly activity constructs, and relates to, the world beyond the subjective self. One way of reading the head trauma of the protagonist-amnesiac in McCarthy's Remainder (2001) is as the result of sensory overload, the impact of which is 
literalised in a surreal fashion through metaphor: he is hit by 'something falling from the sky. Technology. Parts, bits. ${ }^{67}$ The reference to 'bits,' incidentally, can be read as either material parts of technology or as the basic units of information in computing. The novel is obsessed with analysing technological infrastructure, and its communication circuits that impact so heavily on the overladen mind at the start of the twenty-first century; the minimalist style of Remainder depicts what is left of consciousness after overstimulation. Just as Pynchon saw informational entropy as a metaphor for the condition of post-war culture, we should read Remainder as an assessment of our contemporary culture. Future Shock notes:

The culture shocked person, like the soldier and the disaster victim, is forced to grapple with unfamiliar and unpredictable events, relationships and objects. His habitual ways of accomplishing things - even simple tasks like placing a telephone call-are no longer appropriate. The stranger society may itself be changing only very slowly, yet for him it is all new. Signs, sounds and other psychological cues rush past him before he can grasp their meaning. The entire action is shot through with uncertainty. [...] The unpredictability arising from novelty undermines his sense of reality. ${ }^{68}$

The protagonist of Remainder embodies this estrangement and uncertainty about his relationship to the 'real,' and the novel's refusal of denouement makes the work open and unpredictable. $C$ (2010) intensifies McCarthy's investigation of modern communication, with protagonist Serge Carrefax growing up in the early twentieth century, when wireless stations are appearing, filling the air with transmissions, radio waves and other forms of communication. Serge, whose name refers to one of the band members of The Paranoids in Pynchon's The Crying of Lot 49, becomes an aeroplane radio operator during the Great War, and then works for the Ministry of Communications on the Empire Wireless Chain in Egypt. Macauley, who heads the decrypters department, and whose name alludes to McCarthy's own, notes: 'Telegrams, radio messages, acrostics and keywords lurking within print: we try to pick up as much of it as we can. A thankless task, of course; who knows what tiny fraction of it all we actually get. ${ }^{69}$ McCarthy is deeply interested in the potential of noise: Macauley complains that he's bombarded 'all the time with useless information' by an army of information ranging from spies, travellers and novelists, but also claims that the noise they are producing is useful: ${ }^{70}$ 
"With the other parties all spying on us, if we appear to take something seriously, well, they take it seriously too. We call it 'feedback'—no, hang on a second ... 'bleedback': that's it. Lots of those sequences you saw being written out across the blackboards in the other room get bled back too, mutated but still recognisable, in telegrams, transmissions, new acrostics ... Make sure they're confused as we are, eh? Plus, who knows? We might actually hit a nerve, activate something ... maybe ${ }^{71}$

McCarthy's novel activates the potential of noise not only by alluding to its power of deception and function as dynamo of unintended productive consequences in its content, but also through its episodic structuring and the curious future analeptic narration which draws on the speculative realist philosophy of Ray Brassier, who assumes that in the future we are already dead and everything has already happened so that, from this retrospective narratorial position, there is no chaos, just order. ${ }^{72}$

Jennifer Egan's A Visit from the Goon Squad (2010) is an agglomeration of interlinked stories, with no central consciousness or central character, so that the structure mimics the imaginary architecture of our times when humans are networked and complexly connected. This is made explicit in Egan's short story 'Black Box' (2012), first published on Twitter, which transplants one of the characters of Goon Squad, Sasha, as a beautiful woman spy into to a future Mediterranean setting. We read aphoristic messages, which seem to mix a set of collective generalisations from a manual with operating instructions and her succinct, personal thoughts. This doubleness can be explained by the technology built into her body so she is in dialogue with the command centre, who controls and guides agents through a 'Designated Mate', an AI double of the agent. The agent's mind receives Data Surges via a Universal Port: 'You will feel the surge as the data flood your body. The surge may contain feeling, memory, heat, cold, longing, pain, even joy. [...] The impact of a Data Surge may prompt unconsciousness or short-term memory loss. ${ }^{, 73}$ This process of prostheticization of 'citizen agents' allows their mind to separate from their body - the eponymous 'black box.' Similar to $C$ 's future analeptic narration, her thoughts have a curious double temporality, whereby the proleptic structure of feeling of the 'instructions' is simultaneously an account of events already happened. ${ }^{74}$ We can also find Egan's ideas in tech thrillers such as Charles Stross's Accelerando (2005) and Daniel Suarez's Daemon (2009), yet Egan adds to this radical formal experimentation. Egan notes that she had been wondering how to write fiction whose structure would lend itself to serialization on Twitter. This is not a new idea, of course, 
but it's a rich one-because of the intimacy of reaching people through their phones, and because of the odd poetry that can happen in a hundred and forty characters. ${ }^{, 75}$ Egan's story successfully marries the new non-narrative form offered by Twitter up with a meditation on how technology is changing the shape of life in the twenty-first century, from the mind-body relationship and sexual relationships to the question of who controls information and (post)human identity.

Five Star Billionaire (2013) by Tash Aw follows five characters who are seeking fame and fortune in glitzy twenty-first century Shanghai. In order to succeed all of them are on a path to self-transformation, which involves soaking up information of various kinds. Phoebe arms herself with an arsenal of self-help books, Yinghui transforms herself into a successful businesswoman by reading the financial pages in a variety of newspapers, whilst Justin Lim is entranced, and ultimately paralysed, by a blog site that targets his wealthy family:

Soon he was spending all night monitoring the blog site. Sleep evaded him; it was superfluous to his current state. All that seemed relevant to his life was this torrent of words written by unseen, unknown people. [...] He stopped going to the office, for there was nothing left to do now except look at the things people said about him on the blog site. He never strayed far from his laptop, and even if he had to go to the toilet he hurried back as quickly as possible. Taking a shower made him anxious, made him fear that he was missing a new comment on the blog. ${ }^{76}$

Aw's kaleidoscopic Bildungroman revolves around this web of five narratives, and reflects the new economic and informational energies of the eastern Tiger Economies. Aw's modification of the traditional novel form allows the genre to re-direct and reconfigure its function for ordering and transforming the human mind, and contemporary society.

British avant-garde writer Nicola Barker's Clear (2003) is, similarly to Easton Ellis's American Psycho, a novel that absorbs the overwhelming present moment through an abundance of cultural references. ${ }^{77}$ Naomi Alderman, Patrick Ness and James Smythe are three authors interested in information and noise in the digital age. In Alderman's short story written for BBC radio, 'Together' (2013), the protagonist has hit the 5,000 social network friend limit in a future, hyper-networked world where every thought is broadcast directly through social media. The story meditates on loneliness, fictional identity and misunderstandings, and the changing nature of finding love in an ever more crowded world, 
in which peace and silence are becoming an increasingly valuable commodity: 'It is peaceful to turn them off for a while. Many people have turn-off hours, or even turn-off days. Not every thought has to be broadcast. People are fond of repeating this mantra. [...] The very fact that it has to be repeated, of course, is a sign of how little it is understood. ${ }^{78}$ Patrick Ness's Young Adult novel The Knife of Never Letting Go (2008) imagines a world in which through a strange form of telepathy called the Noise everyone can hear other people's thoughts, inspired by information overload. ${ }^{79}$ Through the account of twenty fictional interviewees, Smythe's The Testimony (2012) tells the story of what happens to the world when a deep static noise manifests itself on earth, heard by everyone, from a nun in Vatican City and the White House Chief of Staff to a prisoner on Death Row and a linguistics expert. The characters all have their own interpretation of this droning noise, which slowly turns into intelligible yet cryptic words - 'My Children; Do Not Be Afraid' - after which chaos ensues. ${ }^{80}$ There are many ways of interpreting this conceit, yet one fruitful, critical way is by reading the novel as an inversion of our culture, in which intelligible communication is so often lost in noise. What is striking is that Alderman and Smythe work as computer game writers, an experience which has provided them with an opportunity to rethink how storytelling can reinvent itself in the digital age.

\section{Conclusion: towards a new synthesis in cognitive poetics}

In the twenty-first century, we are overrun by an incredibly noisy world; this is nothing new, yet in the digital age we have seen an intensification, which has generated concern about cognition, memory and our general well-being. The historical analyses in this essay map new subjectivities emerging and questions about what it means to be human in an increasingly posthuman context. Whereas earlier countercultural writers such as Ballard, Pynchon and Burroughs were interested in the nature of information and in the potential for noise as a subversive device, the current concern for the problems of overload is often overtly expressed in many mainstream novels which can often be classified as relatively smooth (genre) fictions that shun formal innovation. These writers also subscribe to the notion of the importance of the brain in cognition, signalling a post-postmodernist shift away from physical and information theory to a perspective in which neuroscience dominates. However, we also see a return to counter-intuitive and playful modes in writers such as Egan and McCarthy, who subvert the very idea and discourse of information overload by denying and invalidating its 
linguistic and ideological credibility and underpinnings whichhave such an appeal in the popular imagination. These fictions create a response to overload at the level of form as well as content return to the sixties interest in noise, jam, glitch and informational entropy. These fictions establish a new symbiosis in which the subject matter is expressed through form, and vice versa, so that we are seeing an emergent cognitive poetics of synthesis in the work of writers such as Foster Wallace, Self, Naomi Alderman, Tash Aw, James Smythe, McCarthy and Egan. Their novels avoid transparent messaging, attempting instead to mimic our culture of Total Noise, and thereby intervene creatively through exposure, blockage, interruption and subversion. These fictions rely on unpredictable informational patternings to suggest that probability is changing dramatically, and that sense-making processes are conditional. Rather than using their novels as a device to create order imaginatively, they acknowledge noise, and use innovative forms that reflect chaos. This new fiction acts as a cognitive space in which these processes are simulated, understood and worked through; the reading of these fictional narratives forges new pathways of thinking about the changing nature of being human.

\section{Works Cited}

Amis, Martin. The Information. London: Flamingo, 1995.

Aw, Tash. Five Star Billionaire. London: Fourth Estate, 2013.

J. G. Ballard, 'The Overloaded Man.’ In The Voices of Time. London: Indigo, 1997. Originally published in 1961.

---. Introduction to Crash. London: Vintage, 1995.

Bernard, Catherine. 'Under the Dark Sun of Melancholia: Writing and Loss in The Information.' In Martin Amis: Postmodernism and Beyond, Keulks, G. (ed.). London and New York: Palgrave-Macmillan, 2006.

Bawden, David and Robinson, Lynne. 'The dark side of information: overload, anxiety and 
other paradoxes and pathologies.' Journal of Information Science, 35 (2009), 180-191.

Bloom, Paul. How Pleasure Works. London: Vintage, 2010.

Brassier, Ray. Nihil Unbound: Enlightenment and Extinction. London: Palgrave Macmillan, 2010. First published in 2007.

Burgess, Anthony. A Clockwork Orange. London: Penguin, 1996. First published in 1962 by William Heinemann.

Cole, Teju. Open City. London: Faber, 2011.

Coplin, Dave. 'Distracted By Work When on Holiday? You Might Be Suffering From Infobesity.' Huffington Post, 17 July, 2014, http://www.huffingtonpost.co.uk/davecoplin/internet-addiction_b_5591831.html [Accessed 9 September 2014]

Cronenberg, David. Consumed. London: Fourth Estate, 2014.

Dror, Itiel. 'Cognitive Technology.' McGraw-Hill Yearbook of Science and Technology 2013, McGraw-Hill Editorial Staff. http://www.cci-hq.com/Dror_MH_Cognitive_Technology.pdf

Eco, Umberto. The Open Work. Trans. Anna Cancogni. Cambridge, Mass.: Harvard UP.

Jennifer Egan. 'Black Box.' New York: Corsair, 2012.

---. 'Coming Soon: Jennifer Egan’s Black Box.' The New Yorker, 23 May, 2012. http://www.newyorker.com/books/page-turner/coming-soon-jennifer-egans-black-box

Eggers, Dave. The Circle: a novel. New York: Vintage, 2014. Originally published by McSweeney's in 2013.

Ellison, Katherine E. Fatal News: Reading and Information Overload in Early EighteenthCentury Literature. London: Routledge, 2008.

Eliot, T. S. The Rock. London: Faber, 1934.

Foster Wallace, David (ed). The Best American Essays 2007. New York: Mariner, 2007.

Gleick, James. The Information: A History, A Theory, A Flood. London: Fourth Estate, 2012. Originally published in 2011.

Glynn, Ian. Elegance in Science. Oxford: Oxford UP, 2013. Originally published in 2013. 
Hall, Donald E. Subjectivity. London and New York: Routledge, 2004.

Hayles, N. Katherine. 'Information of Noise? Economy of Explanation in Barthes's $S / Z$ and Shannon's Information Theory.' In One Culture: Essays in Science and Literature. Levine, G. (ed.). Wisconsin: University of Wisconsin Press, 1987.

---. How We Became Posthuman: Virtual Bodies in Cybernetics, Literature, and Informatics. Chicago: University of Chicago Press, 1999.

Hill, Tobias. The Cryptographer. London: Faber, 2004. First published in 2003.

Iyer, Pico. 'The Joy of the Quiet'. The New York Times, 29 December, 2011.

http://www.nytimes.com/2012/01/01/opinion/sunday/the-joy-ofquiet.html?pagewanted=all\&_r=1\& [Accessed 9 October, 2014]

Johnson, Clay A. The Information Diet: A Case for Conscious Consumption. Sebastopol: O’Reilly, 2012.

Klingberg, Torkel. The Overflowing Brain: Information Overload and the Limits of Working Memory. New York: Oxford UP, 2009.

Tom McCarthy, Remainder. London: Alma, 2010. Originally published in France by Metronome, 2005.

---. $\quad$ Tintin and the Secret of Literature. London: Granta, 2006.

---. C. London: Jonathan Cape, 2010.

McEwan, Ian. The Imitation Game: Three Plays for Television. London: Jonathan Cape 1981. Moggach, Lottie. Kiss Me First. London: Picador, 2013.

Nunes, Mark. Error: Glitch, Noise, and Jam in New Media Cultures. New York and London: Continuum, 2011.

Pynchon, Thomas. The Crying of Lot 49. London: Vintage, 1996. Originally published in Great Britain in 1967.

Roszak, Theodore. The Cult of Information: A Neo-Luddite Treatise on High-Tech, Artificial Intelligence, and the True Art of Thinking. Oakland: University of California Press, 1994. 
Schmid, Siegfried J. 'Der Radikale Konstruktivismus: Ein neues Paradigma im interdisziplinaeren Diskurs' in Der Diskurs des Radikalen Konstruktivismus. Ed. Schmid. Frankfurt: M. Suhrkamp, 1987.

Schweighauser, Philip. 'Information Theory' in The Routledge Companion to Literature and Science, Clarke, B. and M. Rossini, eds. London and New York: Routledge, 2011, pp. 153-54.

Searle, John R. The Mystery of Consciousness. New York: New York Review of Books, 1997.

Self, Will. 'What's in a Brain?' Esquire, Film and Book Special, October 2012, 184-89.

Serres, Michael. The Parasite trans. Lawrence R Schehr. London and Minneapolis: University of Minnesota press, 2007. Originally published as Le Parasite by Grasset \& Fasquellein 1980.

Shenk, David. Data Smog: Surviving the Information Glut. New York: HarperCollins, 1997.

Shields, David. Reality Hunger: a manifesto. London: Penguin, 2010. First published by Hamish Hamilton in 2010.

Shirkey, Clay. Cognitive Surplus: Creativity and Generosity in a Connected Age. New York: Penguin, 2010.

Smith, Zadie. White Teeth. London: Penguin, 2001. Originally published in 2000.

Smythe, James. The Testimony. London: HarperCollins, 2013. First published by Blue Door in 2012 .

Standage, Tom. The Victorian Internet: the Remarkable Story of the Telegraph and the Nineteenth Century's Online Pioneers. London: Phoenix, 1999.

Stein, Gertrude. 'Reflections on the Atomic Bomb'. 1946. http://www.writing.upenn.edu/ afilreis/88/stein-atom-bomb.html

Stiegler, Bernard. Technics and Time, Volume 2: Disorientation, trans. S. Barker. Stanford: 
Stanford UP, 2009. Originally published in French as La Technique et le Temps 2. La Désorientation by Galilée.

Toffler, Alvin. Future Shock. London, Sydney and Toronto: Bodley Head, 1970.

Weaver, Warren. 'Introductory Note on the General Setting of the Analytical Communication Studies.' In Claude E. Shannon's and Warren Weaver's The Mathematical Theory of Communication (Urbana and Chicago: University of Illinois Press, 1963), XXX.

Wright, Adam. Glut: Mastering Information Through the Ages. Washington: Joseph Henry Press, 2007.

Wurman, Richard Saul. Information Anxiety. New York: Doubleday, 1989.

\footnotetext{
${ }^{1}$ Dave Eggers, The Circle: a novel (New York: Vintage, 2014), pp. 497. Originally published by McSweeney's in 2013.

2 James Gleick, The Information: A History, A Theory, A Flood (London: Fourth Estate, 2012), p. 303-4. Originally published in 2011.

${ }^{3}$ Gleick, 403.

${ }^{4}$ Alvin Toffler, Future Shock (London, Sydney and Toronto: Bodley Head, 1970), p.312.

${ }^{5}$ Torkel Klingberg, The Overflowing Brain: Information Overload and the Limits of Working Memory (New York: Oxford UP, 2009), p.165.

${ }^{6}$ See for instance Dave Coplin's 'Distracted By Work When on Holiday? You Might Be Suffering From Infobesity' in the Huffington Post, 17 July, 2014, http://www.huffingtonpost.co.uk/dave-coplin/internetaddiction b 5591831.html. The term 'infobesity' entered the Wiktionary in 2014, yet it was already defined in 2009 in the Netherlands by by a Dutch advertising agency called YoungWorks who specialise in marketing for adolescents. See: http://blog.youngworks.nl/trends/infobesitas

${ }^{7}$ Donald E. Hall writes: 'In the past two decades especially, science and technology have even more dramatically complicated the ongoing discussion of who we are and the extent to which we have agency over the many aspects of our selves. Indeed, given new technologies that allow us to change our physical bodies and augment our abilities in sometimes subtle, sometimes spectacular ways, "what is the self?" and even "what is $a$ self" are questions that are becoming even more difficult to answer.' In: Subjectivity (London and New York: Routledge, 2004), p. 118.

${ }^{8}$ Bernard Stiegler, Technics and Time, Volume 2: Disorientation, trans. S. Barker (Stanford: Stanford UP, 2009), p.134. Originally published in French as La Technique et le temps 2. La Désorientation by Galilée.

${ }^{9}$ Will Self, 'What's in a Brain?', Esquire, Film and Book Special, October 2012, 184-89.

${ }^{10}$ George Steiner quoted by A. S. Byatt in the introduction to Memory: An Anthology, Harriet Harvey Wood and A. S. Byatt, eds. (London: Chatto \& Windus, 2008), p. xv.
} 
${ }^{11}$ Itiel Dror, 'Cognitive Technology', in McGraw-Hill Yearbook of Science and Technology 2013, McGraw-Hill Editorial Staff, see http://www.cci-hq.com/Dror_MH_Cognitive_Technology.pdf [Accessed 11 October, 2013]

${ }^{12}$ This current essay has no space to develop this argument in detail, but it starts with Freud's Civilization and its Discontents (1930), and runs through Marshall McLuhan's Understanding Media (1964) to, in a contemporary context, draw on the extended mind thesis found in Andy Clark's Supersizing the Mind (2011). ${ }^{13}$ Katherine E. Ellison, Fatal News: Reading and Information Overload in Early Eighteenth-Century Literature (London: Routledge, 2008), p. 1.

${ }^{14}$ Alex Wright, Glut: Mastering Information Through the Ages (Washington: Joseph Henry Press, 2007), p.9.

${ }^{15}$ Tom Standage, The Victorian Internet: the Remarkable Story of the Telegraph and the Nineteenth Century's Online Pioneers (London: Phoenix, 1999), p.166. Originally published by Weidenfeld and Nicolson in 1998.

${ }^{16}$ Gertrude Stein, 'Reflections on the Atomic Bomb', http://www.writing.upenn.edu/ afilreis/88/stein-atombomb.html [Accessed 9 September, 2014]

${ }^{17}$ T. S. Eliot, The Rock (London: Faber, 1934), p. 7. See also Gleick's meditation in The Information, pp. 403.

${ }^{18}$ 'History of Bletchley Park', http://www.bletchleypark.org.uk/content/hist/ [Accessed 9 September, 2014]

19 J. G. Ballard, 'The Overloaded Man', in The Voices of Time (London: Indigo, 1997), pp. 79-92; p. 85, 87, 92. Originally published in 1961. The story ends with Faulkner himself disappearing: 'He had not only obliterated the world around him, but also his own body, and his limbs and trunk seemed an extension of his mind, disembodied forms whose physical dimensions pressed upon it like a dream's awareness of its own identity. [..] Slowly he felt the puttylike mass of his body dissolving, it temperature growing cooler and less oppressive. Looking out through the surface of the water six inches above his face, he watches the water six inches above his face, he watched the blue disk of the sky, cloudless and undisturbed, expanding to fill his consciousness. All last he had found the perfect background, the only possible field of ideation, an absolute continuum of existence uncontaminated by material excrescences.' $(91,92)$

20 'Turn it off you grahzny [dirty] bastards, for I can stand no more,' Alex screams in despair. Anthony Burgess, A Clockwork Orange (London: Penguin, 1996), p.89. First published in 1962 by William Heinemann.

${ }^{21}$ For a detailed description, see N. Katherine Hayles, 'The Materiality of Informatics' in How We Became Posthuman: Virtual Bodies in Cybernetics, Literature, and Informatics (Chicago: University of Chicago Press, 1999), pp. 192-221.

${ }^{22}$ Philip Schweighauser, 'Information Theory' in The Routledge Companion to Literature and Science, Clarke, B. and M. Rossini, eds. (London and New York: Routledge, 2011), pp. 153-54.

${ }^{23}$ Thomas Pynchon, The Crying of Lot 49 (London: Vintage, 1996), pp. 72-73. Originally published in Great Britain in 1967.

${ }^{24}$ Mark Nunes, 'Error, Noise, and Potential: The Outside of the Purpose' in Error: Glitch, Noise, and Jam in New Media Cultures', Nunes, M. ed. (New York and London: Continuum, 2011), pp. 3-26; 17.

${ }^{25}$ Ian McEwan, 'The Imitation Game' in The Imitation Game: Three Plays for Television (London: Jonathan Cape 1981), p. 154.

${ }^{26}$ A colleague of Turner crudely asks: 'Shouldn't you first establish whether the woman can think? It's not something one can take for granted, you know.' McEwan, 'Imitation', 163.

${ }^{27} \mathrm{~N}$. Katherine Hayles, 'Information of Noise? Economy of Explanation in Barthes's S/Z and Shannon's Information Theory' in One Culture: Essays in Science and Literature Levine, G. (ed.), (Wisconsin: University of Wisconsin Press, 1987), p.120.

${ }^{28}$ Catherine Bernard, 'Under the Dark Sun of Melancholia: Writing and Loss in The Information', Martin Amis: Postmodernism and Beyond, in Keulks, G. (ed.) (London and New York: Palgrave-Macmillan, 2006), p. 128.

${ }^{29}$ Martin Amis, The Information (London: Flamingo, 1995), p. 63.

${ }^{30}$ David Cronenberg, Consumed (London: Fourth Estate, 2014), pp. 14-15.

${ }^{31}$ David Foster Wallace, Introduction to The Best American Essays 2007 (New York: Mariner, 2007) p.6.

${ }^{32}$ Gleick, 8.

${ }^{33}$ Quoted in Bawden, David and Robinson, Lynne, 'The dark side of information: overload, anxiety and other paradoxes and pathologies', Journal of Information Science, 35, 2009, (180-191), 184.

${ }^{34}$ Stiegler, 137.

${ }^{35}$ Bawden, David and Robinson, Lynne, 'The dark side of information: overload, anxiety and other paradoxes and pathologies', Journal of Information Science, 35, 2009, (180-191), 185. 
${ }^{36}$ I would like to thank Dr Stephan Besser for pointing me towards Der Diskurs des Radikalen Konstruktivismus (1987). The original goes: 'Eine wichtige Einsicht Maturanas besagt, dass lebende Systeme als selbstreferentielle Systeme informationsdicht und strukturdeterminiert sind. Sie haben keinen informationellen Input und Output; sie sind mit anderen Worten energetisch offen, aber informationell geschlossen. Das System erzeugt vielmehr selbst die Informationen, die es verarbeitet, im Prozess der eigenen Kognition.' Siegfried J. Schmid, 'Der Radikale Konstruktivismus: Ein neues Paradigma im interdisziplinaeren Diskurs.' In: Der Diskurs des Radikalen Konstruktivismus. Ed. Schmid. (Frankfurt: M. Suhrkamp, 1987), p.24.

${ }^{37}$ John R. Searle, The Mystery of Consciousness (New York: New York Review of Books, 1997), 16.

${ }^{38}$ Searle, 17.

${ }^{39}$ Ian Glynn, Elegance in Science (Oxford: Oxford UP, 2013), 170. Originally published in 2013.

${ }^{40}$ Klingberg, 3.

${ }^{41}$ Klingberg, 41.

42 Klingberg, 63.

${ }^{43}$ See, for instance, Oprah Winfrey's interview with Franzen: http://www.oprah.com/oprahshow/AuthorJonathan-Franzens-Creative-Process-Video [Accessed 10 September 2014]

${ }^{44}$ See Pico lyer's essay 'The Joy of the Quiet', The New York Times, 29 December, 2011. http://www.nytimes.com/2012/01/01/opinion/sunday/the-joy-of-quiet.html?pagewanted=all\& $r=1 \&$ [Accessed 9 October, 2014]

${ }^{45}$ See the Dutch television programme Pavlov, http://www.uitzendinggemist.net/aflevering/194763/Pavlov.html [Accessed 6 September, 2014)

${ }^{46}$ Ian McEwan talked about his use of Freedom at The Story of Memory literary festival held at UCL, 6 September, 2014. See http://thememorynetwork.net/memory-in-the-twenty-first-century/ [Accessed 6 October, 2014)

${ }^{47}$ Foster Wallace, 2.

${ }^{48}$ Zadie Smith, White Teeth (London: Penguin, 2001), pp. 510-11. Originally published in 2000.

${ }^{49}$ Tobias Hill, The Cryptographer (London: Faber, 2004), p. 148. First published in 2003.

${ }^{50}$ Hill, Cryptographer, 100.

51 'It is the science of concealment, and concealment can be very beautiful. Cryptography can take an alphabet and fold it back onto itself, again and again, like origami, until the letters become numbers and the numbers binary. It can hide the blueprint of a gun in a conversation about snow, the pattern of lights on a train, the genetic structure of a flower. But it can also undo these things.' Hill, Cryptographer, 148.

${ }^{52}$ Hill, Cryptographer, 116.

53 Hill, Cryptographer, 18-19.

${ }^{54}$ Hill, Cryptographer, 254.

${ }^{55}$ Teju Cole, Open City (London: Faber, 2011), Loc 168.

${ }^{56}$ See Antonia Damasio, Self Comes To Mind (New York: Heinemann, 2010) and Dick Swaab, trans. Jane HedleyProle. We Are Our brain (London: Allen lane, 2010).

${ }^{57}$ Haruki Murakami, Colorless Tsukuru Tazaki and His year of Pilgrimage. Trans. Philip Gabriel. (London: Vintage Digital, 2014), Loc 1419, 1526.

58 Lottie Moggach, Kiss Me First (London: Picador, 2013), p. 86.

${ }^{59}$ Klingberg, 56.

${ }^{60}$ Dave Eggers, The Circle: a novel (New York: Vintage, 2014), pp. 411, 413-14. Originally published by McSweeney's in 2013.

61 Klingberg, 163.

62 Michael Serres, The Parasite trans. Lawrence R Schehr (London and Mineapolis: University of Minnesota press, 2007), 126. Originally published as Le Parasite by Grasset \& Fasquellein 1980.

${ }^{63}$ Paul Bloom, How Pleasure Works (London: Vintage, 2010), Loc. 2769.

${ }^{64}$ Self's work has an aesthetics that works against mainstream, smooth literary modus operandi, which finds its analogy in his depiction of London. In Self's first novel, the narrator remarks: 'London, or so its inhabitants like to claim, is a collection of villages. I don't see it like that at all. I see the city as a mighty ergot fungus, erupting from the very crust of the earth; a growing, mutating thing, capable of taking on the most fantastic profusion of shapes.' My Idea of Fun (London: Penguin, 1994), pp. 303-4. First published in 1993.

${ }^{65}$ Tom McCarthy, Tintin and the Secret of Literature (London: Granta, 2006), Loc. 324. 
${ }^{66}$ Tom McCarthy, Tintin and the Secret of Literature (London: Granta, 2006), Loc. 217.

${ }^{67}$ Tom McCarthy, Remainder (London: Alma, 2010), p.5. Originally published in France by Metronome, 2005.

${ }^{68}$ Alvin Toffler, Future Shock (London, Sydney and Toronto: Bodley Head, 1970), pp. 308-9.

${ }^{69}$ Tom McCarthy, C (London: Jonathan Cape, 2010), p. 263.

${ }^{70}$ McCarthy, C, 264.

${ }^{71}$ McCarthy, C, 265.

${ }^{72}$ See Ray Brassier, Nihil Unbound: Enlightenment and Extinction. London: Palgrave Macmillan, 2010. First published in 2007.

${ }^{73}$ Jennifer Egan, 'Black Box', (New York: Corsair, 2012), Loc. 659, 671.First published on Twitter.

${ }^{74}$ Egan, 'Black Box', Loc. 255.

${ }^{75}$ Jennifer Egan, 'Coming Soon: Jennifer Egan's Black Box' (2012), in The New Yorker, 23 May, 2012 http://www.newyorker.com/books/page-turner/coming-soon-jennifer-egans-black-box [Accessed 8 September, 2014]

${ }^{76}$ Tash Aw, Five Star Billionaire (London: Fourth Estate, 2013), 36.

${ }^{77}$ See Sebastian Groes, "Please don't hate me, sensitive girl readers": Gender, Surveillance and Spectacle after 9/11 in Nicola Barker's Clear, in Women's Fiction and Post-9/11 Contexts, ed. Childs, P., C. Colebrook, and S. Groes (New York and London: Lexington, 2015), 159-78.

${ }^{78}$ Naomi Alderman, 'Together', first broadcast on BBC Radio 4 on 7 July, 2013. See http://www.naomialderman.com/together/.

${ }^{79}$ Michael Levy, 'Q \& A with Patrick Ness', 8 October 2009, http://www.publishersweekly.com/pw/bytopic/authors/interviews/article/10556-q-a-with-patrick-ness.html [Accessed 7 September 2014]

${ }^{80}$ James Smythe, The Testimony (London: HarperCollins, 2013), p.94. First published by Blue Door in 2012. 